\title{
SISTEM PENDUKUNG KEPUTUSAN DISKON ASURANSI DENGAN METODE SMARTER
}

\author{
Wiranwan Galeh Pradhana ${ }^{1}$, Albert Yakobus Chandra2 ${ }^{2)}$ \\ Fakultas Teknologi Informasi, Universitas Mercu Buana Yogyakarta, Jl. Jembatan Merah No. 84C Gejayan, \\ Yogyakarta 55283, Indonesia \\ email: ${ }^{1}$ pradhana_wirawan@gmail.com \\ email: ${ }^{2}$ albert.ch@mercubuana-yogya.ac.id
}

\begin{abstract}
In the midst of fierce competition in the market share of car body repair and paint services with independent workshops in Yogyakarta, Nasmoco Bantul is expected to attract as many customers as possible to be able to carry out body and paint repairs, especially customers who use insurance whose percentage reaches $70 \%$ (based on the average monthly invoice data of Nasmoco Bantul). However, this has not reached the expected target because Nasmoco Bantul does not yet have a database that stores customer data complete with the insurance used. So in the research, a database system will be created that will manage and store customer data along with the insurance they use which later information from the database can be used to carry out the marketing process for body paint repairs. And this system is also equipped with an decision support system which aims to assist management in determining the provision of discounts to insurance company partners by using several indicators. This system is a web-based application that uses the CodeIgniter framework. The decision support system method used in determining discounting uses the SMARTER method.
\end{abstract}

Keywords: insurance, database, decision support system, SMARTER method.

\begin{abstract}
Abstrak
Di tengah persaingan ketat pangsa pasar jasa perbaikan bodi dan cat mobil dengan bengkel independen di Yogyakarta, Nasmoco Bantul diharapkan dapat menarik pelanggan sebanyakbanyaknya untuk dapat melakukan perbaikan bodi dan cat terutama pelanggan yang menggunakan asuransi yang prosentasenya mencapai $70 \%$ (berdasarkan rerata data invoice bulanan Nasmoco Bantul). Namun hal tersebut belum mencapai target yang diharapkan karena Nasmoco Bantul belum memiliki database yang menyimpan data pelanggan yang lengkap dengan asuransi yang digunakan. Maka pada penelitian akan dibuat sebuah sistem database yang akan me-manage dan menyimpan data pelanggan berikut dengan asuransi yang mereka gunakan yang nantinya informasi dari database tersebut dapat digunakan untuk melakukan proses pemasaran perbaikan body and paint. Serta sistem ini juga dilengkapi dengan sebuah SPK yang bertujuan untuk membantu pihak management dalam menentukan pemberian diskon kepada rekanan perusahaan asuransi dengan memakai beberapa indikator. Sistem ini merupakan aplikasi berbasis web yang menggunakan framework CodeIgniter. Metode SPK yang digunakan dalam menentukan pemberian diskon menggunakan metode SMARTER.
\end{abstract}

Kata kunci: asuransi, basis data, SPK, metode SMARTER.

\section{PENDAHULUAN}

PT. Nasmoco Bahana Motor (Nasmoco Bantul) merupakan dealer resmi produk Toyota untuk wilayah Daerah Istimewa Yogyakarta yang beralamat di Jl. Ringroad Selatan, Jadan, Tamantirto, Bantul, Yogyakarta. Nasmoco Bantul melayani penjualan mobil baru baik cash maupun kredit, jasa perawatan dan servis mobil, jasa perbaikan bodi dan cat mobil, serta penjualan suku cadang [1]. Selain Nasmoco Bantul terdapat dua dealer Nasmoco lain yang juga beroperasi di wilayah Yogyakarta yaitu PT. Nasmoco Bahtera Motor (Nasmoco Mlati) dan Nasmoco Janti. Dari ketiga dealer tersebut, 
hanya Nasmoco Bantul yang melayani jasa perbaikan bodi dan cat mobil.

Nasmoco Bantul menghadapi persaingan yang cukup ketat dalam menarik pelanggan untuk melakukan perbaikan bodi dan cat, dikarenakan di Yogyakarta sendiri sudah banyak bengkel independen yang juga menyediakan jasa perbaikan bodi dan cat. Bengkel independen memiliki kelebihan terutama pada bagian biaya, karena bengkel independen dapat menekan biaya produksi dengan cara memilih material dan cat dengan kualitas rendah yang tentu saja berbanding lurus dengan kualitas hasil pekerjaan yang tidak sebaik dealer resmi. Namun segmentasi pelanggan yang membayar secara tunai (mobil yang tidak di-cover asuransi) masih lebih memilih menggunakan bengkel independen untuk memperbaiki mobilnya karena jauh lebih murah walaupun dengan kualitas yang tidak bagus [2].

Maka dari itu Nasmoco Bantul terus melakukan aktivitas marketing guna menarik pelanggan untuk datang melakukan perbaikan bodi dan cat, baik itu pelanggan yang menggunakan asuransi maupun yang tidak. Sebagai informasi, komposisi kendaraan milik pelanggan yang pernah melakukan perbaikan di Nasmoco Bantul adalah 70\% customer yang menggunakan asuransi dan 30\% customer yang tidak menggunakan asuransi [3]. Dari data tersebut Nasmoco Bantul berupaya untuk memaksimalkan unit entry yang bersumber dari mobil yang di-cover oleh asuransi. Namun terjadi kendala, karena belum adanya database yang menampung keseluruhan data pelanggan yang menggunakan asuransi untuk kendaraannya. Hal tersebut tentu menjadi kendala karena staff Bodi and Paint tidak mengetahui mana saja pelanggan yang masa berlaku asuransinya. Sebagai informasi, untuk asuransi terbagi 2, yaitu All-Risk dan Total Lost. All-Risk adalah tipe asuransi yang meng-cover seluruh kerusakan yang terjadi pada kendaraan, baik itu kerusakan ringan, sedang hingga kerusakan berat maupun kehilangan baik akibat pencurian maupun bencana. Sedangkan untuk asuransi Total Lost adalah tipe asuransi yang mengganti kerusakan/kerugian apabila kerusakan yang terjadi di atas $75 \%$. Target market yang dibidik Nasmoco Bantul adalah pelanggan yang asuransi yang digunakan tipe All-Risk dan biasanya asuransi tersebut hanya berlaku pada 1 tahun pertama masa kepemilikan mobil. Oleh karena itu sangat penting untuk memiliki database yang dapat menampilkan informasi keseluruhan asuransi yang digunakan pelanggan berikut dengan masa berlakunya [4].

Di samping itu, terkait dengan kerjasama dengan pihak penyedia layanan asuransi masih terdapat masalah. Pihak manajemen belum memiliki sebuah standar dalam menentukan besaran diskon yang akan diberikan kepada pihak asuransi yang bekerja sama dengan Nasmoco Bantul. Untuk itu perlu sebuah sistem yang dapat membantu pihak manajemen dalam mengkalkulasi berbagai data progres kendaraan pelanggan yang di-cover asuransi secara otomatis yang nantinya diharapkan dapat membantu pihak manajemen dalam menentukan besaran diskon yang akan diberikan kepada pihak penyedia layanan asuransi.

Penelitian ini bertujuan untuk membuat suatu sistem database berfungsi untuk menyimpan data pelanggan pengguna layanan asuransi. Sistem tersebut nantinya dapat dimanfaatkan sebagai sarana pemasaran jasa agar pelanggan dapat datang melakukan perbaikan ke Nasmoco Bantul. Sistem database juga diintegrasikan dengan SPK penentuan diskon asuransi dengan menggunakan metode SMARTER yang diharapkan dapat membantu pihak manajemen dalam menentukan besaran diskon yang akan diberikan kepada rekanan perusahaan asuransi dengan beberapa kriteria yang telah dibuat. 


\section{METODE PENELITIAN}

Proses analisis kebutuhan yang dijalankan dalam pengembangan sistem ini database asuransi yaitu dengan studi litaratur dengan mempelajari konsep dan materi yang berhubungan dengan dengan teori dan pengembangan sistem database yaitu sekumpulan data yang terorganisir [5] dan SPK yang tercantum dalam berbagai literatur. Bentuk literatur tersebut antara lain dalam bentuk buku teks, paper, jurnal, website, dll. Kemudian melalui pengamatan langsung ke lapangan serta mengumpulkan dokumen tentang data terkait dengan penelitian di Nasmoco Bantul. Pengumpulan data dan informasi dengan wawancara bertujuan untuk mengetahui permasalahan dan spesifikasi sistem yang dibutuhkan oleh user dan manejemen terkait dengan sistem yang akan dibuat dan diimplementasikan di Nasmoco Bantul.

Sistem database yang akan dibangun merupakan aplikasi berbasis website yang merupakan halaman yang diunggah ke domain dan diakses melalui sebuah browser [6]. Alasan membuat aplikasi berbasis website karena penggunaannya lebih mudah dan praktis karena dapat digunakan di berbagai macam web browser. Kemudian bahasa pemrograman yang digunakan dalam pembuatan sistem adalah PHP (Hypertext Preprocessor) yang merupakan bahasa pemrograman server web yang open souce [7]. Untuk kerangka pembuatan aplikasi penulis menggunakan framework yang sudah memiliki dasar himpunan dan fungsi yang dibutuhkan dalam membangun sebuah aplikasi [8]. Framework yang digunakan adalah CodeIgniter karena cocok untuk pengembangan aplikasi berbasis web karena sifatnya yang dinamis [9]. Serta untuk aplikasi web server peneliti menggunakan XAMPP yang dapat digunakan disemua platform sistem operasi komputer [10]. Alur penelitian dalam perancangan sistem database dapat dilihat pada Gambar 1.

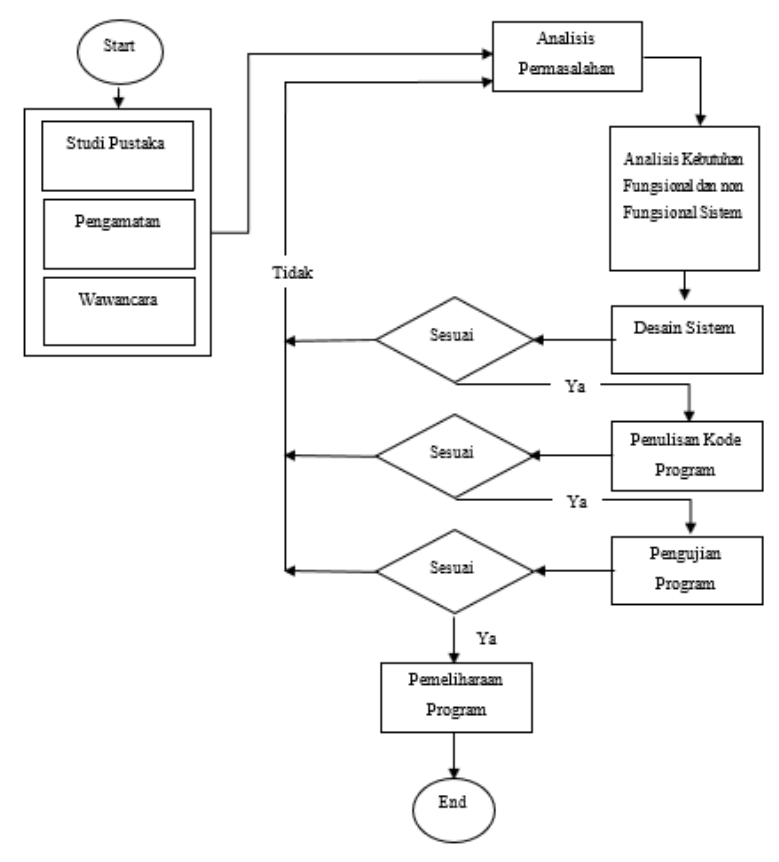

Gambar 1. Alur Penelitian

\section{SMARTER (Simple Multi-Attribute}

Rating Technique Exploiting Ranks) merupakan sebuah metode perhitungan matematis decision making process yang multiatribut yang dikembangkan pada tahun 1994 oleh Edward and Baron. Metode decision making process multikriteria ini berdasarkan teorema yaitu tiap alternatif terbentuk dari beberapa kriteria yang memiliki value serta tiap kriteria mempunyai bobot yang memperlihatkan level kepentingan kriteria tersebut jika dikomparasikan dengan kriteria lainnya [11]. Sistem perhitungan bobot metode SMARTER memakai range dari nol sampai satu, sehingga memudahkan proses kalkulasi dan pembandingan value pada masing-masing alternatif [12]. Penghitungan bobot dengan metode SMARTER dilakukan dengan memakai rumus perhitungan bobot RankOrder Centroid (ROC). Rumus ROC ini berdasarkan level prioritas dari beberapa kriteria [13]. Rumus bobot $R O C$ dihasilkan dengan perhitungan matematika sederhana tentang prioritas. Pemahaman dasarnya direpresentasikan dengan meggunakan dua variebel, yaitu variebel $A$ dan variebel $B$. Apabila ranking A prioritas no.1, maka value pembobotan harus diantara angka 
0,5 dan angka 1 sehingga midpoint of interval 0,75 dijadikan value dari bobot perkiraan, yang menjadi dasar prinsip minimum commitment. Kemudian bobot pada variebel B adalah 0,25 (midpoint dari angka 0 dan angka 0,5). Prosedur tersebut dijabarkan sebagai berikut (apabila terdapat K kriteria) [14]. Berikut merupakan rumus perhitungan bobot menggunakan rumus $R O C$ :

$W_{k}=\frac{1}{K} \sum \frac{1}{i}$

Pada Rumus (1) di atas tersebut menjelaskan $W$ sebagai bobot kriteria sebagai nilai patokan awal yang akan dicari. Kemudian $K$ merupakan variabel yang menunjukkan banyaknya kriteria yang sudah ditentukan. Kemudian untuk $k$ merupakan urutan dari kriteria yang ada. Berikut merupakan penjabaran pada Rumus (1).

If $w_{i}>w_{2}>\ldots>w_{k}$ then,

$W_{1}=\frac{1+\frac{1}{2}+\frac{1}{3}+\cdots+\frac{1}{K}}{K}$

$w_{2}=\frac{0+\frac{1}{2}+\frac{1}{3}+\cdots+\frac{1}{K}}{K}$

$w_{3}=\frac{0+0+\frac{1}{3}+\cdots+\frac{1}{K}}{K}$

$w_{K}=\frac{0+\cdots+0+\frac{1}{K}}{K}$

Langkah selanjutnya adalah menentukan nilai multiatribut di dalam metode SMARTER dengan menggunakan Rumus (7) di bawah ini. Proses perhitungan nilai utility, value tersebut didapatkan melalui penjumlahan dari value setiap kriteria, kemudian hasilnya dikalikan dengan value dari perhitungan bobot subkriteria, lalu dijumlahkan [15]. Variabel $v$ merupakan nilai utility yang akan dihitung. Kemudian $k$ sama seperti Rumus (1) merupakan urutan dari kriteria yang ada. Juga untuk $W$ yang mana merupakan banyaknya kriteria yang sudah ditentukan.

$v(a)=\sum W_{k} \cdot V_{k} \mid \mathrm{K}=1,2, \ldots . \mathrm{n}$
Langkah berikutnya adalah kalkulasi nilai akhir. Dengan penjabaran $w_{j}$ merupakan nilai bobot dari kriteria tertentu. Kemudian $\mu_{i j}$ merupakan nilai utility setiap kriteria. Dan $n_{i}$ merupakan nilai akhir perankingan dari semua alternatif yang ada, dapat dilihat pada Rumus (8).

$n_{i}=\sum n w_{j} \mu_{i j}$

Kemudian nilai utility dikali value pembobotan kriteria adalah hasil penetapan opsi alternatif yang akan digunakan. Keseluruhan langkah-langkah penyelesaian dengan menggunakan metode SMARTER yaitu, langkah pertama adalah menetapkan seluruh kriteria yang akan digunakan sebagai dasar. Langkah kedua yaitu membuat perankingan terhadap posisi untuk tiap-tiap kriteria yang ada, dengan tingkat kepentingan sebagai dasar penentuannya. Langkah ketiga, melakukan proses perhitungan bobot untuk setiap kriteria yang sudah ditetapkan dengan menggunakan rumus Rank Order Centroid sesuai dengan Rumus (1). Langkah keempat yaitu melakukan proses perhitungan bobot untuk setiap sub kriteria yang sudah ditetapkan dengan menggunakan rumus $R O C$ sama seperti perhitungan nilai bobot kriteria pada Rumus (1). Langkah kelima, kalikan hasil perhitungan $R O C$ pada Rumus (3), Rumus (4), Rumus (5) hingga Rumus (6) disesuaikan dengan jumlah kriteria guna memperoleh nilai bobot akhir pada masing-masing kriteria tersebut. Langkah keenam, untuk memperoleh hasil nilai akhir kriteria, nilai pembobotan akhir pada tiap kriteria dikalikan dengan nilai prioritas, langkah selanjutnya jumlahkan seluruh hasil akhir kriteria tersebut guna memperoleh total nilai akhir kriteria guna menghasilkan keseluruhan nilai akhir semua kriteria. Langkah ketujuh yaitu memberikan nilai utilitas pada tiap-tiap nilai kriteria serta sub kriteria. Langkah kedelapan, melakukan proses perhitungan urutan perankingan akhir untuk seluruh 
opsi yang ada. Hasil akhir perangkingan yang memiliki nilai paling besar akan ditetapkan menjadi opsi terbaik untuk keputusan pemberian diskon.

\section{HASIL DAN PEMBAHASAN}

\subsection{Penerapan Metode SMARTER dalam Penelitian}

\subsubsection{Menentukan Jumlah Kriteria}

Pada proses penentuan diskon asuransi yang akan diberikan kepada perusahaan rekanan penyedia jasa asuransi, terdapat beberapa kriteria yang menjadi dasar acuan. Kriteria tersebut didapat dari hasil wawancara dengan pihak manajemen Nasmoco Bantul. Kriteria tersebut dapat dilihat pada Tabel 1 .

\begin{tabular}{ll}
\multicolumn{2}{c}{ Tabel 1. Tabel Kriteria } \\
\hline No. & \multicolumn{1}{c}{ Kriteria } \\
\hline 1. & Jumlah Unit \\
2. & Nilai Klaim \\
3. & Leadtime SPK Terbit \\
4. & Leadtime SPH Terbit \\
\hline
\end{tabular}

\subsubsection{Menentukan Nilai Bobot Setiap Kriteria}

Setiap kriteria memiliki memiliki tingkat rank yang berbeda-beda dalam menghasilkan keputusan, berdasarkan hasil wawancara dengan pihak management Nasmoco Bantul maka didapat rank kriteria penentuan diskon seperti pada Tabel 2. Kemudian hitung nilai bobotnya menggunakan pembobotan ROC (Rank Order Centroid) sesuai dengan Rumus (1).

Tabel 2. Tabel Nilai Bobot Kriteria

\begin{tabular}{llll}
\hline No. & \multicolumn{1}{c}{ Kriteria } & Rank & Nilai Bobot \\
\hline 1. & Jumlah Unit & 1 & 0,52 \\
2. & Nilai Klaim & 2 & 0,27 \\
3. & Leadtime SPK & 3 & 0,15 \\
4. & Leadtime SPH & 4 & 0,06 \\
\hline
\end{tabular}

\subsubsection{Menentukan Sub-Kriteria dan Nilai Bobotnya}

Setelah mendapatkan nilai dari kriteria yang diperoleh dari data klaim asuransi, langkah selanjutnya adalah melakukan normalisasi nilai tiap subkriteria. Lalu diubah sesuai nilai bobot sub-kriteria masing-masing yang sesuai dengan perhitungan pembobotan ROC (Rank Order Centroid) sama dengan Rumus (1). Hasil perhitungan dapat dilihat pada Tabel 3 .

\begin{tabular}{llll}
\multicolumn{3}{c}{ Tabel 3. Tabel Sub-Kriteria dan Nilai Bobotnya } \\
\hline No. & Kriteria & \multicolumn{1}{c}{ Sub-Kriteria } & $\begin{array}{c}\text { Nilai } \\
\text { Bobot }\end{array}$ \\
\hline 1. & Jumlah Unit & $>=60$ unit & 0,52 \\
& & $40-59$ unit & 0,27 \\
& & $20-39$ unit & 0,15 \\
& & $<20$ unit & 0,06 \\
\hline 2. & Nilai Klaim & $>=$ Rp 200jt & 0,52 \\
& & Rp. 100jt - Rp. 199 jt & 0,27 \\
& & Rp. 50 jt - Rp. 99 jt & 0,15 \\
& & $<$ Rp. 50 jt & 0,06 \\
\hline 3. & Leadtime & $1-3$ hari & 0,52 \\
& SPK & $4-6$ hari & 0,27 \\
& & $7-9$ hari & 0,15 \\
& & $>9$ hari & 0,06 \\
\hline 4. & Leadtime & $1-3$ hari & 0,52 \\
& SPH & $4-6$ hari & 0,27 \\
& & $7-9$ hari & 0,15 \\
& & $>9$ hari & 0,06 \\
\hline
\end{tabular}

\subsubsection{Menentukan Nilai Utility}

Nilai utility diperoleh dari perkalian antara nilai bobot kriteria dengan nilai bobot sub-kriteria. Cara perhitungan nilai utility menggunakan Rumus (7). Hasil perhitungan dapat dilihat pada Tabel 4 .

Tabel 4. Tabel Nilai Utility

\begin{tabular}{|c|c|c|c|}
\hline No. & Kriteria & Sub-Kriteria & $\begin{array}{c}\text { Nilai } \\
\text { Utility }\end{array}$ \\
\hline \multirow[t]{4}{*}{1.} & Jumlah & $>=60$ unit & 0,270 \\
\hline & Unit & 40-59 unit & 0,140 \\
\hline & & 20-39 unit & 0,078 \\
\hline & & $<20$ unit & 0,031 \\
\hline \multirow[t]{4}{*}{2.} & Nilai Klaim & $>=$ Rp. 200jt & 0,140 \\
\hline & & Rp. 100jt - Rp. 199 jt & 0,073 \\
\hline & & Rp. 50 jt - Rp. 99 jt & 0,041 \\
\hline & & $<$ Rp. 50 jt & 0,016 \\
\hline \multirow[t]{4}{*}{3.} & Leadtime & 1-3 hari & 0,078 \\
\hline & SPK & 4-6 hari & 0,041 \\
\hline & & 7-9 hari & 0,023 \\
\hline & & $>9$ hari & 0,009 \\
\hline \multirow[t]{4}{*}{4.} & Leadtime & 1-3 hari & 0,031 \\
\hline & SPH & 4-6 hari & 0,016 \\
\hline & & 7-9 hari & 0,009 \\
\hline & & $>9$ hari & 0,004 \\
\hline
\end{tabular}

\subsubsection{Menentukan Nilai Akhir}

Nilai akhir diperoleh dari perkalian antara nilai utility dengan nilai alternatif kemudian hasil keseluruhan dijumlahkan. Maka akan diperoleh nilai perankingan yang nantinya dapat dijadikan bahan pertimbangan oleh pihak management 
untuk menentukan pemberian diskon bagi rekanan perusahaan asuransi. Perhitungan menggunan Rumus (8). Hasil perhitungan dapat dilihat pada Tabel 5.

\begin{tabular}{lllll}
\multicolumn{5}{c}{ Tabel 5. Tabel Nilai Akhir } \\
\hline No. & \multicolumn{1}{c}{ Asuransi } & Nilai Akhir & Rank & Diskon \\
\hline 1. & ACA & 0,158171 & 1 & $33 \%$ \\
2. & CAKRAWALA & 0,152959 & 2 & $25 \%$ \\
3. & RAMAYANA & 0,124032 & 3 & $20 \%$ \\
4. & SIMAS & 0,085829 & 4 & $15 \%$ \\
5. & ADIRA & 0,073984 & 5 & $10 \%$ \\
\hline
\end{tabular}

\subsection{Struktur Database}

Perancangan database merupakan proses untuk menentukan isi data yang dibutuhkan untuk mendukung rancangan sistem database yang dibangun oleh model relationship. Dimana seluruh tabel saling berhubungan. Rancangan database yang berisi tabel data yang digunakan nantinya akan diimplementasikan ke dalam sistem. Gambaran relasi antar tabel ditampilkan pada Gambar 2.

\subsubsection{Tabel User}

Tabel User digunakan untuk menyimpan data user. User merupakan personal yang dapat mengakses dan menggunakan sistem database. Struktur tabel user dapat dilihat pada Tabel 6.

\begin{tabular}{llcl}
\multicolumn{4}{c}{ Tabel 6. Tabel User } \\
\hline Nama & Tipe & Size & Keterangan \\
\hline id & integral & 11 & Primary \\
username & varchar & 25 & \\
password & varchar & 25 & \\
\hline
\end{tabular}

\subsubsection{Tabel Service Advisor}

Tabel Service Advisor digunakan untuk menyimpan data personel Service Advisor. Data Service Advisor nantinya akan digunakan pada laporan akhir data klaim. Struktur tabel Service Advisor dapat dilihat pada Tabel 7.

\begin{tabular}{lccc} 
& \multicolumn{3}{c}{ Tabel 7. Tabel Service Advisor } \\
\hline \multicolumn{1}{c}{ Nama } & Tipe & Size & Keterangan \\
\hline id & integral & 10 & Primary \\
nama & varchar & 50 & \\
inisial & varchar & 25 & \\
\hline
\end{tabular}

\subsubsection{Tabel Asuransi}

Tabel Asuransi digunakan untuk menyimpan data nama perusahaan asuransi yang bekerja sama dengan Nasmoco Bantul. Data Asuransi ini akan digunakan dalam perhitungan diskon dan dicantumkan pada laporan data klaim. Struktur tabel Asuransi dapat dilihat pada Tabel 8.

\begin{tabular}{llcl}
\multicolumn{4}{c}{ Tabel 8. Tabel Asuransi } \\
\hline \multicolumn{1}{c}{ Nama } & Tipe & Size & Keterangan \\
\hline id & integral & 10 & Primary \\
nama & varchar & 50 & \\
abbr & varchar & 50 & \\
\hline
\end{tabular}

\subsubsection{Tabel Kendaraan}

Tabel Kendaraan digunakan untuk menyimpan data kendaraan milik pelanggan Nasmoco Bantul. Data kendaraan ini juga digunakan dalam perhitungan diskon. Struktur tabel Kendaraan dapat dilihat pada Tabel 9.

\begin{tabular}{llll}
\multicolumn{4}{c}{ Tabel 9. Tabel Kendaraan } \\
\hline \multicolumn{1}{c}{ Nama } & \multicolumn{1}{c}{ Tipe } & Size & Keterangan \\
\hline nopol & varchar & 12 & Primary \\
no_rangka & varchar & 30 & \\
identitas & text & & \\
sim & date & & \\
stnk & date & & \\
\hline
\end{tabular}

\subsubsection{Tabel Polis}

Tabel Polis digunakan untuk menyimpan data polis asuransi yang digunakan pada kendaraan milik pelanggan. Data polis terintegrasi dengan data kendaraan pada Tabel 9 dan data asuransi pada Tabel 8. Struktur tabel Polis dapat dilihat pada

\begin{tabular}{llll}
\multicolumn{4}{c}{ Tabel 10. Tabel Polis } \\
\hline \multicolumn{1}{c}{ Nama } & \multicolumn{1}{c}{ Tipe } & Size & Keterangan \\
\hline id & $\begin{array}{l}\text { integral } \\
\text { date }\end{array}$ & 10 & Primary \\
tanggal_mulai & & \\
tanggal_berakhir & $\begin{array}{l}\text { date } \\
\text { integral }\end{array}$ & 10 & Foreign \\
$\begin{array}{l}\text { id_asuransi } \\
\text { nopol_kendaraan } \\
\text { dokumen }\end{array}$ & $\begin{array}{l}\text { varchar } \\
\text { text }\end{array}$ & 12 & Foreign \\
\hline
\end{tabular}

\subsubsection{Tabel Kriteria}

Tabel Kriteria digunakan untuk menyimpan data kriteria. Data tersebut digunakan sebagai acuan dalam perhitungan ROC (Rank Order Centroid) untuk perhitungan diskon kepada perusahaan rekanan penyedia jasa asuransi menggunakan metode SMARTER. Struktur tabel Kriteria dapat dilihat pada Tabel 11. 
Tabel 11. Tabel Kriteria

\begin{tabular}{llll}
\hline \multicolumn{1}{c}{ Nama } & \multicolumn{1}{c}{ Tipe } & Size & Keterangan \\
\hline id & integral & 10 & Primary \\
keterangan & varchar & 255 & \\
rank & integral & 5 & \\
target & varchar & 255 & \\
\hline
\end{tabular}

\subsubsection{Tabel Sub-Kriteria}

Tabel Sub-Kriteria digunakan untuk menyimpan data sub-kriteria. Data tersebut nantinya akan digunakan sebagai acuan dalam perhitungan ROC (Rank Order Centroid) untuk perhitungan diskon menggunakan metode SMARTER. Struktur tabel Sub-Kriteria dapat dilihat pada Tabel 12.

Tabel 12. Tabel Sub-Kriteria

\begin{tabular}{llll}
\hline \multicolumn{1}{c}{ Nama } & \multicolumn{1}{c}{ Tipe } & Size & Keterangan \\
\hline id & integral & 10 & Primary \\
id_kriteria & integral & 11 & Foreign \\
keterangan & varchar & 255 & \\
value & varchar & 255 & \\
rank & integral & 5 & \\
nilai_real & integral & 5 & \\
\hline
\end{tabular}

\subsubsection{Tabel Klaim}

Tabel Klaim digunakan untuk menyimpan data klaim asuransi kendaraan. Data yang disimpan dalam Tabel Klaim tersebut merupakan keseluruhan dari data yang di-input ke sistem dan nantinya diolah oleh sistem dengan metode SMARTER sehingga dapat menghasilkan rekomendasi pemberian diskon. Struktur tabel Klaim dapat dilihat pada Tabel 13.

\begin{tabular}{llll}
\multicolumn{4}{c}{ Tabel 13. Tabel Klaim } \\
\hline \multicolumn{1}{c}{ Nama } & \multicolumn{1}{c}{ Tipe } & \multicolumn{1}{c}{ Size } & \multicolumn{1}{c}{ Keterangan } \\
\hline id & integral & 10 & Primary \\
id_polis & $\begin{array}{l}\text { integral } \\
\text { integral }\end{array}$ & 10 & Foreign \\
id_serviceadvisor & 10 & Foreign \\
nilai_klaim & decimal & 15,2 & \\
tgl_dok_kirim & date & & \\
tgl_spk_terbit & date & & \\
tgl_sph_terbit & date & & \\
tgl_revisi & date & & \\
tgl_acc_revisi & date & & \\
tgl_banding & date & & \\
tgl_acc_banding & date & & \\
\hline
\end{tabular}

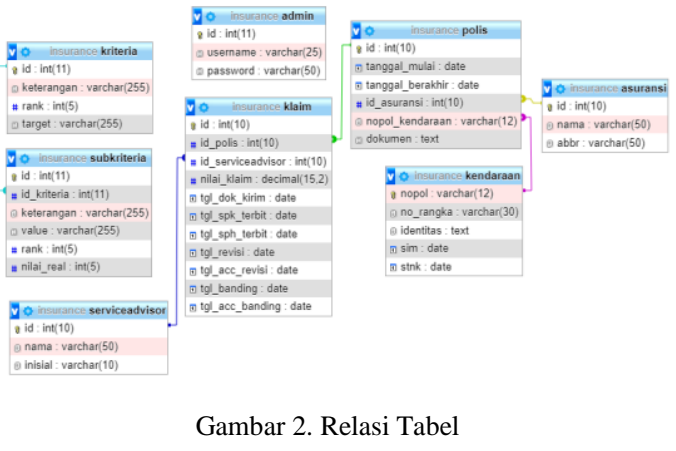

3.3 Tampilan Antar Muka (User Interface)

3.3.1 Tampilan Login

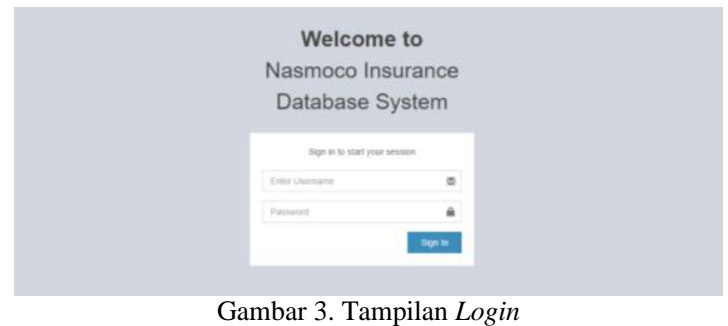

Sebelum masuk ke dalam sistem, user harus melakukan proses login terlebih dahulu. Jika username dan password yang dimasukkan oleh user benar maka sistem akan membuka akses aplikasi tersebut kepada user, namun jika username dan password yang dimasukkan salah maka user, maka sistem akan menampilkan informasi yang meminta user untuk memasukkan data yang benar. Gambar 3Error! Reference source not found. merupakan tampilan pada Halaman Login ketika user akan masuk ke dalam sistem.

\subsubsection{Tampilan Dashboard Grafik}

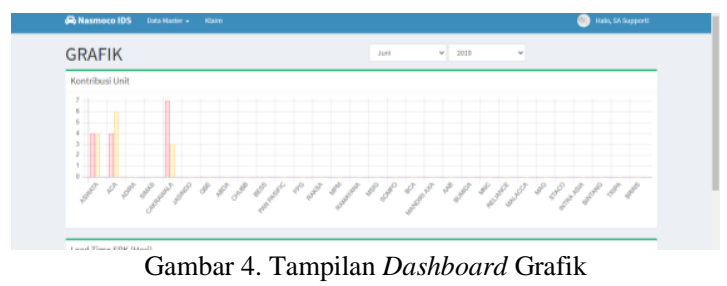

Halaman ini menampilkan informasi umum terkait beberapa indikator pencapaian asuransi baik dari klaim, penerbitan SPK dan SPH yang ditampilkan dalam bentuk grafik. Data diambil dan diproses dari data yang disimpan pada 
Tabel Klaim yang dapat dilihat pada Tabel 13. Gambar 4 merupakan tampilan dari halaman dashboard grafik.

\subsubsection{Tampilan Master Asuransi}

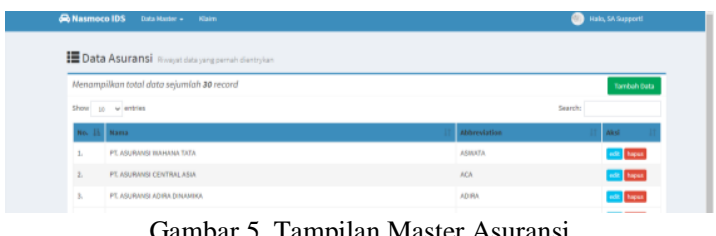

Gambar 5. Tampilan Master Asuransi

Menu Master Asuransi berfungsi untuk mengelola data rekanan perusahaan asuransi yang melakukan kerja sama dengan Nasmoco Bantul. Admin dapat melakukan proses add, edit dan delete data asuransi. Gambar 5Error! Reference source not found. merupakan tampilan halaman Master Asuransi.

\subsubsection{Tampilan Master Service Advisor}

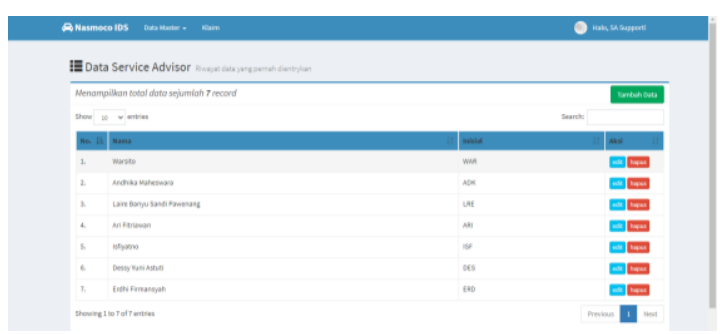

Gambar 6. Tampilan Master Service Advisor

Menu Master Service Advisor berfungsi untuk mengelola data service advisor yang berkerja di Nasmoco Bantul. Data service advisor nantinya akan ditampilkan pada laporan data klaim bulanan. Admin dapat melakukan proses add, edit dan delete data Service Advisor. Gambar 6 merupakan tampilan halaman Master Service Advisor.

\subsubsection{Tampilan Master Kendaraan}

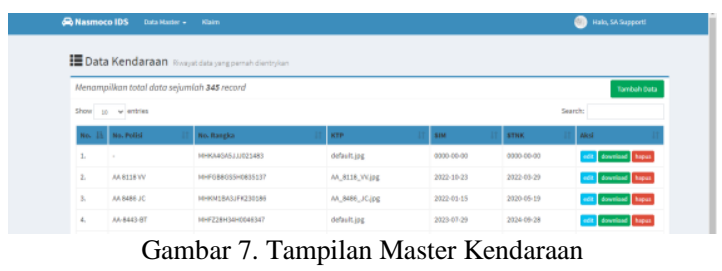

Halaman yang berfungsi untuk mengelola data kendaraan milik pelanggan yang nantinya akan diolah untuk melakukan kegiatan pemasaran jasa perbaikan bodi dan cat. Admin dapat melakukan proses add, edit dan delete data kendaraan. Gambar 7 merupakan tampilan halaman Master Kendaraan.

\subsubsection{Tampilan Master Polis}

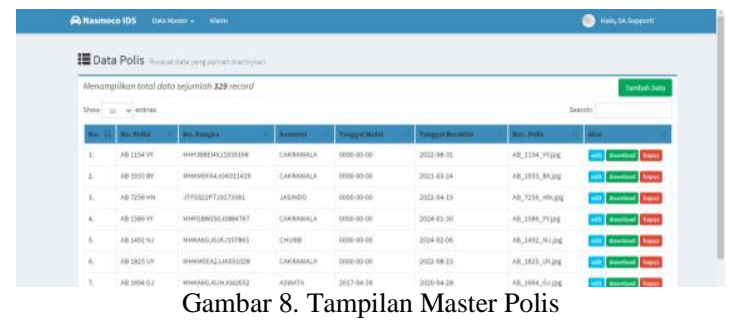

Menu Master Polis berfungsi untuk mengelola data polis asuransi yang digunakan pada kendaraan milik pelanggan yang nantinya akan diolah untuk aktivitas pemasaran jasa perbaikan bodi dan cat. Data polis juga diolah oleh sistem untuk perhitungan diskon. Admin dapat melakukan proses add, edit dan delete pada data polis. Gambar 8 merupakan tampilan Master Polis.

\subsubsection{Tampilan Halaman Kriteria}

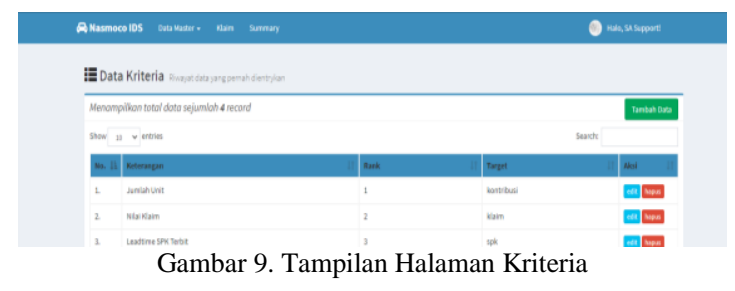

Menu Kriteria berfungsi untuk mengelola data kriteria yang digunakan sebagai acuan dalam perhitungan $R O C$ (Rank Order Centroid) untuk perhitungan diskon kepada perusahaan rekanan penyedia jasa asuransi menggunakan metode SMARTER. Data kriteria tersebut nantinya akan diproses oleh sistem dengan menggunakan Rumus (1). Admin dapat melakukan proses add, edit dan delete pada data kriteria. Gambar 9 merupakan tampilan halaman Kriteria. 


\subsubsection{Tampilan Halaman Sub-Kriteria}

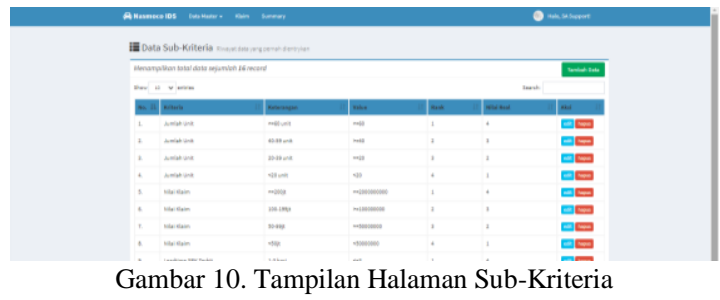

Menu Sub-Kriteria berfungsi untuk mengelola data sub-kriteria yang digunakan sebagai acuan dalam perhitungan ROC (Rank Order Centroid) untuk perhitungan diskon kepada perusahaan rekanan penyedia jasa asuransi menggunakan metode SMARTER. Data sub-kriteria tersebut nantinya akan diproses oleh sistem dengan menggunakan Rumus (1) sama seperti pada perhitungan bobot kriteria. Admin dapat melakukan proses add, edit dan delete pada data subkriteria. Gambar 10 merupakan tampilan halaman Sub-Kriteria.

\subsubsection{Tampilan Data Klaim}

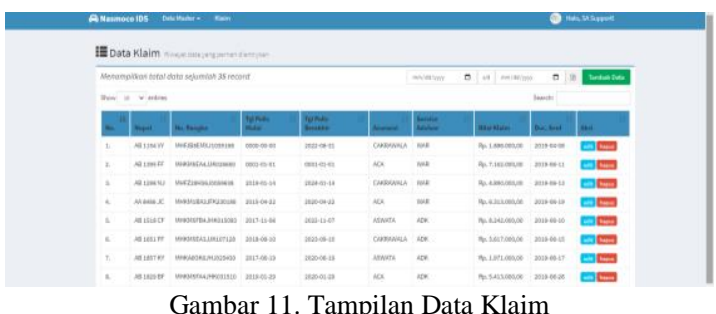

Gambar 11. Tampilan Data Klaim

Menu Data Klaim berfungsi mengelola data klaim asuransi kendaraan milik pelanggan yang melakukan proses perbaikan bodi dan cat di Nasmoco Bantul. Admin dapat melakukan proses add, edit dan delete pada data klaim. Gambar 11 merupakan tampilan halaman Data Klaim.

\subsubsection{Tampilan Summary}

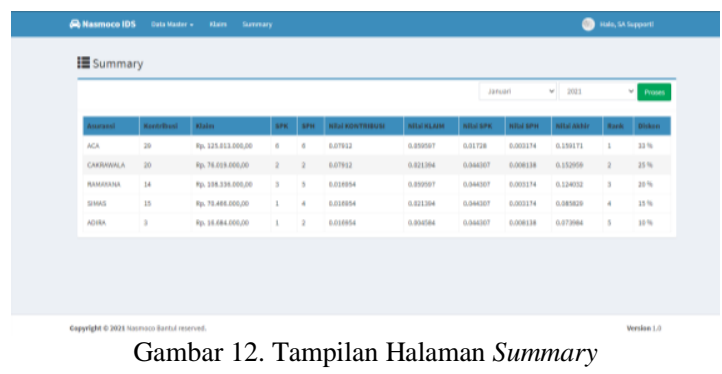

Menu Summary berfungsi untuk menampilkan rekomendasi diskon asuransi setelah mengolah data dalam database menggunakan metode SMARTER. Detail hasil perhitungan sistem dibandingkan dengan perhitungan manual pada Tabel 5 ditampilkan pada Gambar 13. Es summary

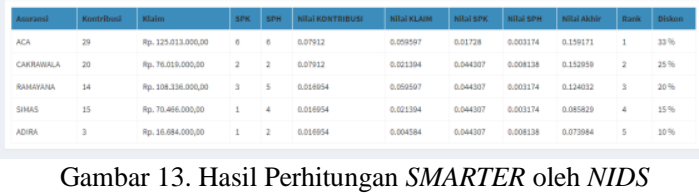

\section{SIMPULAN}

NIDS (Nasmoco Insurance Database System) merupakan sistem database yang berfungsi untuk mengelola keseluruhan data pelanggan yang berhubungan dengan asuransi dan proses klaimnya. NIDS (Nasmoco Bantul Insurance System) dapat membantu proses pemasaran jasa perbaikan body and paint serta memberikan data keluaran berupa laporan klaim asuransi yang dapat diatur range waktu laporan yang akan dicetak serta rekomendasi pemberian diskon asuransi pada rekanan penyedia jasa asuransi. NIDS (Nasmoco Bantul Database System) dapat membantu pihak manajemen dalam menentukan besaran diskon yang akan diberikan kepada perusahaan rekanan penyedia jasa asuransi dengan mengolah keseluruhan data transaksi menggunakan metode SMARTER dengan hasil yang lebih cepat dan efisien karena diproses secara otomatis oleh sistem. Saran pengembangan yang dapat dilakukan pada penelitian selanjutnya adalah pengembangan untuk dapat menghubungkan NIDS dengan aplikasi perpesanan seperti Whatsapp, Telegram, atau $S M S$. Dengan pengembangan aplikasi pada bagian tersebut dapat mempermudah bagi admin telemarketing SA support selaku operator NIDS untuk dapat melakukan aktivitas pemasaran perbaikan body and paint kepada pelanggan sehingga dengan hal tersebut diharapkan dapat meningkatkan jumlah pelanggan yang melakukan perbaikan ke Nasmoco Bantul yang tentunya berimplikasi pada 
meningkatnya profit yang didapatkan perusahaan.

\section{DAFTAR PUSTAKA}

[1] S. N. Untari, S. Djaja, and J. Widodo, "Strategi Pemasaran Mobil Merek Daihatsu Pada Dealer Daihatsu Jember," J. Pendidik. Ekon. J. Ilm. Ilmu Pendidikan, Ilmu Ekon. dan Ilmu Sos., vol. 11, no. 2, p. 82, 2018.

[2] A. N. Dhanistha and Djuwityastuti, "PROSES PEMBAYARAN KLAIM ASURANSI KENDARAAN BERMOTOR BAGI TERTANGGUNG (Studi di Brins General Insurance Cabang Yogyakarta)," J. Priv. Law, vol. 7, no. 1, p. 130, 2019.

[3] H. S. Rotua Tinambunan, B. Waskito, M. B. Rizhaldi, and A. F. K.R. Uno, "Asuransi Kecelakaan Kendaraan Bermotor Roda Dua Sebagai Moda Transportasi Umum Berbasis Online," J. Huk. Ius Quia Iustum, vol. 26, no. 3, pp. 627-649, 2019.

[4] S. Zulkifli, L. Meidina, S. H. Dhalimunthe, and I. C. Ginting, "Implementasi Prinsip Subrogasi pada Asuransi Kendaraan Bermotor: Studi pada PT Pan Pacific Insurance," SIGn J. Huk., vol. 2, no. 1, pp. 20-29, 2020.

[5] A. D. Hardiansyah, D. C. Nugrahaeni, P. Dewi, and M. Kom, "Perancangan Basis Data Sistem Informasi Perwira Tugas Belajar (Sipatubel) Pada Kementerian Pertahanan," J. Senamika, vol. 1, no. 2, pp. 222-233, 2020.

[6] P. S. Hasugian, "Perancangan Website Sebagai Media Promosi Dan Informasi," J. Inform. Pelita Nusant., vol. 3, no. 1, pp. 82-86, 2018.

[7] Fitri Ayu and Nia Permatasari, "perancangan sistem informasi pengolahan data PKL pada divisi humas PT pegadaian," J. Infra tech, vol. 2, no. 2, pp. 12-26, 2018.

[8] A. Asroni, "Penerapan Model View Controller (MVC) Dengan Framework Codeigniter Pada Sistem Informasi Booking Wisata Klangon," BERDIKARI J. Inov. dan Penerapan Ipteks, vol. 6, no. 2, pp. 119-130, 2018.

[9] S. Tyowati and R. Irawan, "Implementasi Framework Codeignter Untuk Pengembangan Website Pada Dinas Perkebunan Provinsi Kalimantan Tengah," J. SAINTEKOM, vol. 7, no. 1, p. 67, 2017.

[10] S. Nirsal, Rusmala, "Desain Dan Implementasi Sistem Pembelajaran Berbasis E-Learning Pada Sekolah Menengah Pertama Negeri 1 Pakue Tengah," J. Chem. Inf. Model., vol. 10 , pp. 21-25, 2020.

[11] A. Haris, B. Satria, and M. I. Ukkas, "Penerapan Sistem Penunjang Keputusan Pemberian Diskon Pada Reseller Dengan Metode Simple Multi-Attribute Rating Technique Exploiting Ranks (Smarter)," vol. 7, no. 2, pp. 31-37, 2017.

[12] A. Rizkiyanto and I. G. Anugrah, "Implementasi Metode Simple Multy Attribute Rating Technique Exploiting Ranks (Smarter) Dan Forward Chaining Pada Penentuan Posisi Karyawan Baru PT. Langgeng Buana Jaya, Gresik," J. Nas. Komputasi dan Teknol. Inf., vol. 2, no. 2, p. 149, 2019.

[13] A. Saleh, "Penerapan Metode Simple Multi Attribute Rating Technique Exploiting Rank dalam Sistem Pendukung Keputusan Rekrutmen Asisten Laboratorium Komputer," J. Masy. Telemat. dan 
Inf., vol. 8, pp. 1-10, 2018.

[14] M. Simarmata, "Penerapan Metode Smarter Dalam Sistem Pendukung Keputusan Menentukan Kualitas Getah Karet (Studi Kasus : Ptpn Iii Medan)," J. Masy. Telemat. Dan Inf. J. Penelit. Teknol. Inf. dan Komun., vol. 10, no. 1, p. 13, 2019.
[15] M. A. Ramadhan, C. Bella, Mustakim, R. Handinata, and A. Niam, "Implementasi Metode SMARTER Untuk Rekomendasi Di Pekanbaru," J. Ilm. Rekayasa dan Manaj. Sist. Inf., vol. 4, no. 1, pp. 42-47, 2018. 